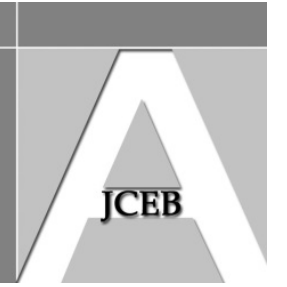

\section{Dimensions of Organisational Culture Quantity Surveying Firms in Nigeria}

Ayokunle Olubunmi Olanipekun, Joseph Ojo Abiola-Falemu \& Isaac Olaniyi Aje

Federal University of Technology, Akure, Nigeria

\begin{abstract}
The functionalist paradigm of organisational culture (OC) views culture as a variable subject to conscious manipulation and control in order to solve organisational challenges. Therefore, this paper provides information on how $\mathrm{OC}$ is a solution to the challenges in Quantity Surveying firms (QSFs). This was achieved by eliciting the dimensions of OC in forty two QSFs in Lagos, Nigeria, which are the business, people and external environment dimensions. The paper concludes that $\mathrm{OC}$ is a relevant solution to the identity and management related challenges in QSFs. Specifically, the paper informs on the implications of business and people dimensions of $\mathrm{OC}$ as a solution to the identity challenges, as well as on the implication of the external environment dimension of OC to the management challenges. Based on the findings, recommendations are directed at the management and employees QSs in QSFs and Quantity Surveying researchers.
\end{abstract}

Keywords: Dimensions of Organisational culture, Quantity Surveying firms, functionalist paradigm, identity, management

\title{
INTRODUCTION
}

Quantity Surveying Firms (QSFs) are service based that manage finance related issues for clients in the construction industry (Abidin et al. 2011), using infrastructure cost and value management expertise (Olanipekun, Aje \& Abiola-Falemu 2013). In QSFs, employee Quantity Surveyors (QSs) provide the expertise, knowledge and skill relied upon for service delivery. This indicates their importance to the performance of QSFs, which is in line with Espejo (2000); Lawrence and Lorsch (1967).

One of the contexts in which organisations can be studied is their cultural effects. As opined by Zhang and Liu (2006), there are factors that seem to permeate organisational life and influence every aspect of organisation operation, and one of such is organisational culture (OC). According to Pandey (2014), OC lays the foundation of an organisation, builds and nurtures it, defines its purpose, sets its direction, prioritizes its tasks, guides its strategies and behaviour of its people and ultimately delivers its results. This implies OC forms an integral part of the general functioning of an organisation (Martins \& Terblanche 2003). That is; OC epitomises the expressive character of an organisation. By definition, OC is a basic assumption, as well as the findings, invention, and development of an organisation dealing with external adaptation and internal integration (Wu \& Lin 2013). This means that as groups evolve over time, they face two basic challenges: integrating individuals into an effective whole, and adapting effectively to the external environment in order to survive. As groups find solution to these problems over time, they engage in a kind of collective learning that creates the set of shared assumption and beliefs called culture (Ojo 2010).

\footnotetext{
Australasian Journal of Construction Economics and Building 2014. ( 2014 Ayokunle Olubunmi Olanipekun et al. This is an Open Access article distributed under the terms of the Creative Commons Attribution 4.0 Unported (CC BY 4.0) License (https://creativecommons.org/licenses/by/4.0/), allowing third parties to copy and redistribute the material in any medium or format and to remix, transform, and build upon the material for any purpose, even commercially, provided the original work is properly cited and states its license.
}

Citation: Olanipekun A O, Abiola-Falemu J O \& Aje I O. 2014, 'Dimensions of Organisational Culture in Quantity Surveying Ffirms in Nigeria', Australasian Journal of Construction Economics and Building, 14 (4), 54-70.

http://dx.doi.org/10.5130/ajceb.v14i4.54 
The functionalist paradigm of $\mathrm{OC}$ views culture as a variable subject to conscious manipulation (Gajendran et al. 2012). In other words, OC is amenable to control. From this perspective it is possible to manage culture and to link culture to organisational performance, thereby implying a causal relationship (Gajendran et al. 2012). In corroboration, Pandey (2014), states that the study of OC gives solutions to most of organisational problems. In other words, a better understanding of the concept would allow people in organisations to solve problems and improve performance (Ojo 2010). Past research by Ramachandran (2013), Aldhuwaihi, Shee and Stanton (2012), Mathew, Ogbonna and Harris (2012), Su, Yang and Yang (2012), Dharmayanti, Coffey and Trigunarsyah (2011), Shaikh (2011), Ankrah (2007), Issa and Haddad (2007), Zhang and Liu (2006) and Lok and Crawford (2004) has explored and affirmed the potential of $O C$ to solve problems within organisations.

Managerial and identity related challenges confront QSFs, and threatens their existence, growth and success (performance). In Nigeria, a developing country, the manifestations of these challenges are limited diffusion of the services of QSFs, inability of QSFs to directly secure jobs from clients, and inability of the QSFs to attract and retain quality QS personnel amongst others. It is important to address these problems so that QSFs can deliver high service performance in the Nigerian construction industry. Given the evidence exemplifying the possibility of addressing organisational challenges using $\mathrm{OC}$, it is proposed that there is a relationship between the performance challenges of QSFs in Nigeria and their OC. It must be emphasised that OC exists in every organisation, including QSFs, whether noticed or not, desired or not, articulated or not (Pandey 2014; Ng \& Kee 2013; Line 1999). Thus as a first step, this paper quantitatively elicits the OC in QSFs in Nigeria, prior to establishing relationship(s) with their performance in future research.

There are typology and dimension approaches to studying OC. Both are used to capture or represent important aspects of culture (Kessel, Oerlemans \& Stroe-Biezen 2014). Though typologies are easier to comprehend, real cases correspond more with dimensions than typologies (Ankrah \& Langford 2005; Hofstede 1997). Thus a dimension approach was adopted in this study, specifically the Organisational Culture Profile (OCP)'s business, people and environmental dimensions of OC. In terms of corresponding with real cases, the dimensions of OCP (Business, People and Environmental) relate well with the profit, client/employee and competitiveness orientation of QSFs respectively. Therefore in addition to eliciting the OC, the theoretical implications of the three dimensions for QSFs' performance challenges are given. That is, how does the OC in QSFs theoretically apply to solving the identified challenges? Findings of this research have implications for the management and employees of QSFs and Quantity Surveying researchers. The paper is structured as follows. First, a review of literature relevant to OC and the nature and challenges of QSFs is presented. Then the research method is described followed by the presentation of research findings.

\section{Literature Review}

\section{Organisational Culture (OC)}

OC has been described in different perspectives in the literature (Pandey 2014; AbiolaFalemu 2013; Shaikh 2011; Zhang \& Liu 2006; Martins \& Terblanche 2003). In Ng and Kee (2013) OC is defined as the collective programming of the mind which distinguishes the members of one organisation from another. In another definition, $\mathrm{OC}$ is the pattern of shared values and beliefs that help individuals understand organizational functioning and thus provide them with the norms for behaviour in the organization (Ramachandran 2013; Coffey, Willar \& Trigunarsyah 2011). Taken together, OC is a distinguishing attribute (Pandey 2014; Rameezdeen \& Gunarathna 2012; Aluko 2003), which is learned by people over the time period which they spend within the organization (Aftab, Rana \& Sawar 2012; Liu \& Fellows 2008), and eventually determines their perceptions and feelings and to some degree, their overt behaviour (Gajendran \& Brewer 2012). 
There are three levels or manifestation of OC: artefacts, values, and assumptions (Guevara 2014; Ng \& Kee, 2013; Abiola-Falemu, Ogunsemi \& Oyediran 2010; Parker \& Bradley 2000). Artefacts are the visible structures and processes of an organisation, the architecture of its physical environment, its style, emotional displays, observable rites and ceremonies and, not least, its products (Guevara 2014; Igo \& Skitmore 2005). Thus the manifestation of the artefact level OC in QSFs may be the Softwares for preparing Bills of Quantities (BOQ), the unique way of preparing and presenting BOQs or their project focus, which is largely on construction cost. However, artefact level does not provide deeper understanding of OC in QSFs (Guevara 2014). The second level of organisational culture comprises espoused beliefs, mental processes, knowledge and values (Barthorpe, Duncan \& Miller 2000), where the strategy, goals and philosophy of an organisation are located, publicly justifying its existence, mission and measures (Guevara 2014). Assumptions, which are the unconscious taken-for-granted beliefs, perceptions, thoughts and feelings, are located at the third level of OC (Guevara 2014; Parker \& Bradley 2000). Guevara (2014) however reiterates that contradictions showing at levels one and two can often be explained through the set of an organisation's implicit assumptions. In other words, assumption level of OC forms the ultimate source of organisational values and actions.

The philosophical conceptualisations of culture are mainly divided between the functionalist (culture as a variable) and non-functionalist (culture as a metaphor) paradigms (Gajendran \& Brewer 2012; Gajendran et al. 2012; Maull, Brown \& Cliffe 2001). The non-functionalist paradigm treats $\mathrm{OC}$ as a root metaphor whereby culture is more comprehensively described to explain human behaviour and its context, such that the behaviour becomes meaningful to an outsider (Gajendran et al. 2012). In this paradigm, reality is defined as subjective and multi-dimensional, with the possibility of different meanings attached to the same phenomenon (Wilson 2000). Also the philosophical stance of the non-functionalist paradigm of $O C$ is more attuned to the qualitative research methodology (Gajendran et al. 2012). Conversely, the functionalist paradigm treats $\mathrm{OC}$ as something which may be influenced, changed and manipulated and in turn influences, changes and manipulates members and features of the organisation (Wilson 2000). In other words, basic values, assumptions and beliefs become enacted in established form of behaviours and activity that are reflected as structures, policies, practices, management practices and procedures (Gajendran et al. 2012; Martins \& Terblanche 2003). This means outcomes e.g. performance, are embedded in the organisation's cultural symbols (values, assumptions, beliefs etc.) and when implemented, become the behaviour of members (See Guevara 2014; Aftab, Rana \& Sarwar 2012; Ojo 2010; Martins \& Terblanche 2003).

Thus OC is revealed in the actions and behaviour of employees (Abdul Halim et al. 2014) or conversely, in order to understand an organisation's observable behaviour patterns, it is crucial to understand its culture (Guevara 2014). Based on the behaviour (a reflection of OC) of employees in an organisation, customers or clients understand the culture of such organisation, and then form their own perceptions (Pandey 2014). Hence, if the customers' or clients' perception is positive, it is good for the organisations' market share, brand image etc., and if not, the organisation loses patronage (Pandey 2014). Another way in which OC influences employee behaviour towards performance is that culture improves employees' ties with one another (social embeddedness) (Kessel et al. 2014), and this increases the tendency of organisations to retain top performers and also attract new staff (Ojo 2010). Drawing on all these, $\mathrm{OC}$ is as a predictive and explanatory construct (Liu, Shuibo and Meiyung, 2006), that subscribes to the quantitative methodology (Gajendran et al. 2012; Maull, Brown \& Cliffe 2001; Wilson 2000) or the functionalist paradigm.

In this paper, the notion is that through the functionalist paradigm, the three levels of OC (artefacts, values and assumptions) which embed organisational outcomes, when implemented, becomes the behaviour of employee QSs, and could be modified to improve the performance challenges in QSFs. Performance can be at the individual, work or process and organisational levels. However, individual and work performance levels translate to the 
organisational level (Aftab, Rana \& Sarwar 2012), and thus the former is adopted in describing the performance of QSFs in this paper. Under certain circumstances the performance of an organisation is the account of how it progresses from state A to state $B$, the latter being in some way better than the former (Jirasinghe 2006).

\section{Nature and Challenges of Quantity Surveying Firms (QSFs)}

Quantity surveying firms (QSFs) are service oriented organisations providing cost and value management expertise on infrastructure procurement (Olanipekun, Aje \& Abiola-Falemu, 2013; Abidin et al. 2011; Smith 2011; Fong \& Choi 2006) in the construction industry. Predominantly QSFs rely on the skills, expertise, and knowledge of Quantity Surveyors (QSs) to satisfy clients' needs (Oyediran 2011; Nor, Mohamed \& Egbu 2011; Fong \& Choi 2006; Sonia 2005). This suggests the importance of people, or employee QSs to QSFs, and, as service based firms, their products are in the form of expert advice, services and consultancy (Abidin et al. 2011). In the past QSFs offered only traditional services such as valuation of the works in progress and settlement of final accounts (Pheng \& Ming 1997). However, owing to competitive drives (Chong, Lee \& Lim 2012; Smith 2004; Pheng \& Ming 1997) and the need for survival and profitability (Ofori \& Toor 2012; Abidin et al. 2010; Smith 2004), QSFs have expanded their scope of services (Zhou et al. 2012). The expanded services include among others, taxation advice, insurance valuations etc. (Smith 2011; Smith 2004).

Similar to other professional and management organisations, information technology (IT) is important to the success of QSFs (Smith 2004). For instance, BIM, if implemented in QSFs, will enable QSs to do work, or render their service more accurately and efficiently (Gee 2010). Though IT could be regarded as positive for QSFs, it also comes with some negatives (Smith 2011; Gee 2010; Smith 2004). Negatively, the use of BIM reduces the cost management task of QSs, almost making them irrelevant (Gee 2010). For QSFs the negativity and positivity that comes with IT is like being at cross roads on the decision to move from the past to the present (Ofori \& Toor 2012). Thus the adoption of a technology such as BIM is low among UK's QSFs (Zhou et al. 2012), while less than half of the QSFs in Malaysia use measurement software application for Bill of Quantities (BOQ) preparation (Keng \& Ching 2012). This appears like a problem for QSFs cutting across both developed and developing Nations.

QSFs are not without further challenges, most of which threatens their existence, growth and success (Frei \& Mbachu 2013). According to Matipa, Kelliher and Keane (2009), consultancies tend to have a relatively small number of personnel, and Aliyu (2011), Smith (2011), Hardie et al. (2005) and Smith (2004) allude this assertion to QSFs. It is a challenge because QSFs will find themselves in dissonance to the logic of 'the bigger, the better' in business parlance. For instance, due to the smallness nature of QSFs, the research of Hardie et al. (2005) find that they do not innovate because of lack of money and time. Lack of time could be attributed to lack of adequate personnel to complete tasks on time. Other problems facing QSFs globally include the inability to deliver value for clients due to lack of value management knowledge (Bowen et al. 2010), and low diffusion of services rendered among clients due to poor marketing (Pheng \& Ming 1997). One instance is Nigeria where many have still not come to terms with what quantity surveying as a profession is all about (Kadiri \& Ayodele 2013), which is a question of identity (Onwusonye 2013).

In Australia and New Zealand, where Quantity Surveying practice is vibrant and active, QSFs' challenges include: fee cutting and bidding amongst firms, increased legal action due to professional indemnity insurance, the development of CAD, high level of QSFs' conservatism especially in terms of IT utilisation, incursion and encroachment of other professions, poor marketing and quality of graduates (Frei \& Mbachu 2013; Smith 2004; Smith 2011). In Nigeria, a major problem of QSFs is that they tie their fortunes to friendly architecture and engineering firms because they cannot directly secure job commission from clients (Oyediran 2011). This practice has succeeded in shielding the identities of QSFs from 
private clients in Nigeria (Kadiri \& Ayodele 2013). Other challenges faced by QSFs in Nigeria include weak business structure which no longer satisfies the present day business environment (Annunike 2011), low quality personnel due to the inability of the firms to train, motivate and retain specialist employees (Aliyu 2011), inadequacy of organisational resources e.g. stationary, resulting in low productivity (Ogunsemi, Oke \& Awodele 2013), and outdated operational techniques (Atinuke 2010). In Nigeria, the problems of QSFs could be summarised into identity and organisational related, both of which may have contributed to the subsisting unimpressive delivery of Quantity Surveying practice in Nigeria (Onwusonye 2013; Fagbemi 2008).

In the literature there are few construction related researches focusing on OC. Majority of these researches evaluate the influence on OC on different social phenomenon in construction companies in different locations. Coffey's (2003) is company effectiveness (Hong Kong), Issa \& Haddad's (2008) is knowledge sharing (USA), while Giritli et al.'s (2013) is leadership (Turkey). Oluwatayo, Amole and Adeboye (2014) and Albayrak and Albayrak (2014) only assess OC in descriptive terms in construction and architecture organisations respectively. The research of Liu and Fellows (2008) is the only research on OC in QSFs. The research investigates the effects of QSs' collective orientation (manifestation of culture) on their citizenship behaviour in various organisations. The findings of the research have implications only for QSs, which sharply contrasts the focus on QSFs in this paper. Therefore this paper contends that OC exists in QSFs, with theoretical implications for organisational challenges.

\section{Conceptual Framework}

In the literature review it was seen that culture is an effective variable that can be manipulated to enhance organisational outcomes. Also, there are challenges confronting QSFs, which have impacted on their performance and relevance. Thus this research asserts that OC is an effective tool to improve the organisational outcomes in QSFs. At first, and adopting the Dimensions of Organisational Culture (DOC), this research seeks to elicit the culture in QSFs and then describe in theoretical terms how it applies to the identified challenges. Though there are various theories, models or tools for understanding and diagnosing OC (Suppiah \& Sandhu 2012), the Organisational Culture Profile (OCP) by Sarros et al. (2005) was adopted. The OCP has three dimensions; business, people and the environment. The three dimensions cover the areas that are important to service organisations like QSFs as they are business oriented (profit), environment oriented (competitiveness) and people oriented (employees and clients). These dimensions are described below.

\section{Business Dimension of Organisational Culture}

This dimension of OC emphasises goal accomplishment (Olanipekun 2012), achievement or competitiveness (Davies, Nutley \& Mannion 2000), and innovativeness (Sarros et al. 2005). In other words, organisations with this dimension of OC expect their human resources to be competitive (Katamba 2010; Delobbe, Haccoun \& Vandenberghe 2005), and quick to adapt quickly to opportunities (Alas, Ubius \& Vanhala 2011). Further, such organisations allow openness to criticism, sharing of knowledge, sharing of information freely, encouragement of new ideas and taking risks (Khan et al. 2010). Consequently the organisations are productive, competitive and profitable (Alas et al. 2011).

\section{People Dimension of Organisational Culture}

The people dimension of $\mathrm{OC}$ has supportiveness and emphasis on reward as its sub cultures (Sarros et al. 2005). Supportiveness sub culture describes values or norms for interpersonal relationships and further, indicates the degree to which work activities are organized around teams rather than individuals (Katamba 2010). Reward sub culture 
emphasises the degree to which reward allocations are based on employee performance in contrast to seniority, favoritism or any other non-performance criterion (Katamba 2010). Thus the emphasis of people dimension of OC is concern for humanistic aspect in organisations (Vedina \& Vadi 2007; Gray \& Densten 2005; Davies et al., 2000). In manifesting the supportiveness sub culture, organisations do help provide training and counselling opportunities for their employees (Khan et al. 2010) which could lead to improved performance in line with Ankrah (2007). Also performance based reward promotes equity and competitiveness in organisations.

\section{External Environment Dimension of Organisational Culture}

Largely, this dimension of $\mathrm{OC}$ concerns for aspects in the external environment beyond the organization (Sarros et al. 2005). The sub cultures of this dimension are stability and social responsibility (Gray, Densten \& Sarros 2003). In organisations, stability sub culture emphasises stability, execution of regulations and internal maintenance, and strives for consistency and control through clear tasks (Bashayreh 2009; Nel 2009). Also, social responsibility sub culture entails developing relationships with the society through positive contributions in the process of conducting organisational business. By implication, this dimension of OC determines the way in which organisational structure and support mechanisms contribute to the effectiveness of the organisation (means to achieve objectives), and focuses the image of the organisation to the outside world (whether it is a sought-after employer) (Mansor \& Tayib 2010). Therefore it is more suited to larger organisations (Cameron 2004). In summary, when an organisation is balanced internally and externally, it is well positioned for success.

\section{Research Methodology}

\section{Research Design, Instrument and Method of Analysis}

The literature review above describes $\mathrm{OC}$ as a tool which can be used in organisations to improve outcomes. On this basis, this research investigates the dimensions of OC in QSFs in Nigeria. A survey method was used in eliciting necessary data for the study. Yin (2009) states that survey designs provide the best research method when prevalence and the incidence of a phenomenon are of interest. In this research, the interest is to investigate the pervasiveness of the dimensions of OC in QSFs with a view to giving their implications for addressing the identified challenges. Secondary data obtained through a literature review of relevant publications and information sourced from libraries and internet was used. The secondary data led to the tentative statement, and expressed using the OCP. The OCP provides the basis for measuring empirical research and was used in compilation of the questionnaire for the survey.

Thus in questionnaire compilation, the OCP is a standard questionnaire organised into three dimensions with the three dimensions further subdivided into seven sub-dimensions (e.g. Business dimension: innovation, performance orientation and competitiveness; People dimension: reward and supportiveness; External environment dimension: social responsibility and stability) and the seven sub-dimensions operationalised into four measurable items each, making a total of twenty eight. Since the OCP is a standard questionnaire, there was the need to modify the questions/measurables to engender the understanding of the respondents. For instance, a question/measurable under innovation is 'being innovative'. This was modified as: 'in this firm, innovative and creative ways of doing things are encouraged'. The manner of questioning in the questionnaire followed the rating of the extent of agreement with the cast measurables using 5-point Likert scale, with range of 5 as 'strongly agree' to 1 as 'strongly disagree'. In addition to the part of the questionnaire that contains the dimensions of $\mathrm{OC}$, the general part elicited information on the hierarchy of respondents. Before sending out the questionnaire, it was tested for reliability using the Cronbach's Alpha test. Cronbach's Alpha test measures internal consistency, which 
describes the extent to which all the items in a test measure the same concept or construct and hence it is connected to the inter-relatedness of the items within the test (Tavakol \& Dennick 2011; Cortina 1993).

The population for this study is the database of QSFs in Lagos, Nigeria. Within the QSFs, the focus was on the three identified hierarchies of employees (Principal Partner, Senior, and Junior Quantity Surveyors). The identification and subsequent administration of questionnaires to these different hierarchies was to allow for robust and all inclusive response since perception of $\mathrm{OC}$ can vary among hierarchies in organisations. In support, Corley (2004) states that; one of the intriguing boundaries in which an organisation can be differentiated is organisational hierarchy and is seen to play significant role in determining the perceptions of organisational members. The total of 42 QSFs in Lagos Nigeria (data obtained from the Secretariat of the Nigerian Institute of Quantity Surveyors, Lagos State of Nigeria chapter) was sampled since they are within manageable size. In order to ensure that the questionnaires were administered to the identified hierarchies within the QSFS, purposive sampling was used i.e. the questionnaires were purposively given only to the QSs that are within each of the hierarchy. This implies at least three questionnaires were given per QSF.

\section{Data Analysis}

Prior to carrying out the data analysis, a reliability test was carried out to find out if it was reasonable to go ahead. Cronbach alpha test was carried out on the data and the result was as follows: Business dimension (performance orientation culture $=0.80$; competitiveness culture $=0.81$; innovation $=0.89$ ), people dimension (reward culture $=0.82$; supportiveness culture $=0.83$ ) and environment dimension (social responsibility culture $=0.87$; stability culture $=0.83$ ). Given the above Cronbach alpha values, the research instrument was thus adjudged reliable based on the George and Mallery (2000) rule of thumb, where Cronbach's alpha $(\alpha)$ value $\geq 0.8$ for research instruments was considered good. The analysis of the response on the agreement or disagreement on the dimensions of OC in QSFs was done using mean score. The mean score represents the average of the agreement among respondents on the questions being asked. To determine the direction of agreement of respondents, the mean score premise of decision of Johns (2010) was used. Johns (2010) stated that for a Likert scale that uses a 'decided' midpoint, the midpoint is a useful means of determining what might otherwise be a more or less random choice between agreement and disagreement. In this case, the mid-point of the 5-point Likert scale is 2.5 , meaning that any measurable in this paper having a mean score $\geq 2.5$ will be considered the agreed choice with respect to the question. Since there are three hierarchies of Quantity Surveyors, Kruskal-Wallis $\mathrm{H}$ test was carried to ascertain if there's significant difference in their opinion of the subject matter. The Kruskal-Wallis one-way analysis-of-variance-by-ranks test (or $\mathrm{H}$ test) is used to determine whether three or more independent groups are the same or different on some variable of interest when an ordinal level of data or an interval or ratio level of data is available (Chan \& Walmsley 1997).

\section{Firms' and Respondents' Details}

Forty two QSFs in Lagos were sampled, with one questionnaire for each of the three identified hierarchies. This makes a total of one hundred and twenty six questionnaires administered, out of which ninety $(71.42 \%)$ were returned and used for analysis. The breakdown of responses show that there were 21 Principal Partners (23.34\%), 29 Senior Quantity Surveyors (32.22\%) and 40 Junior Quantity Surveyors (44.44\%). Notably, the response is skewed towards the lower hierarchy. This may not be unconnected with the fact that the responsibilities of higher hierarchies in most organisations, including QSFs are mostly outside the boundary of organisations. Such responsibilities include pursuing business opportunities and attending industry meetings. With this happening, there is less time devoted to issues they consider less important such as completing questionnaires. 
However the 21 Principal Partner and 29 Senior Quantity Surveyor responses received could be counted upon for dependability, owing to the organisational knowledge they derive and exhibit in their positions. Across the three hierarchies of Quantity Surveyor respondents, 26.7\%, 45.6\% and 27.8\% are academic holders of Higher National Diploma (HND), Bachelor and Master Degrees respectively. Professionally, 8 out of the 21 Principal Partners are Fellows of the Nigerian Institute of Quantity Surveyors (FNIQS). This is the highest professional qualification in Quantity Surveying in Nigeria, and this qualification is not awarded untill after more than 15 years of professional practice and service with unblemished record. This is an advantage to this research considering the professional exposure category. The other respondents (91.11\%) are corporate members of the NIQS. Thus it could be inferred that the respondents who participated in the survey are both academically and professionally grounded, which should give credibility to the data collected.

The unit of analysis in this paper is the organisation, and thus it is important to focus on long standing organisations. It is logical to expect long standing organisations to have more robust OC than newly established. Thus out of the 42 QSFs, 18 were established over 15years ago, 15 had between 10-15 years in existence while the remaining 9 had about 5 years in existence. Given that the majority of the QSFs had longer years in existence, the respondents were asked if their respective QSFs had unified values, norms and practices that could be counted as their OC. All the 90 respondents from the 42 QSFs responded 'yes' The agreement of respondents on the existence of OC in QSFs may not be unconnected with the fact that the majority of firms have been in existence for a long time. Furthermore, all the QSFs have non-corporatised organisational structure (OS). 40 (95.24\%) of the QSFs are partnerships, while the other two (4.76\%) are sole-proprietorships. Since the focus of this research was not on organisation structure, and neither was the research dependent on the structure of QSFs, their non-corporatization would not impair the findings thereof.

\section{Dimensions of Organisation Culture in Quantity Surveying Firms}

The survey results of the dimensions of OC in QSFs are shown on Table 1. The business, people and external environment are the dimensions of OC in QSFs. Their group mean values are 4.35, 4.31 and 4.38 respectively. Obviously these mean score values are greater than the mid-point 2.50 threshold of John's (2010), implying that the respondents confirm by agreeing to have business, people and external environment as dimensions of OC in QSFS. That is, there are three dimensions of OC in QSFs. The analysis was done in line with the operationalisation of each of the three dimensions of organisational culture into distinct seven sub-cultures. For the business dimension, the mean scores for competitiveness sub culture by Principal Partner (PP), Senior Quantity Surveyor (SQS) and Junior Quantity Surveyor (JQS) are 4.48, 4.79 and 4.45 respectively. For the performance orientation sub culture, the mean scores by PP, SQS, and JQS are 4.19, 4.28 and 4.25 while their mean values for innovation sub culture are $4.38,4.10$ and 4.13 respectively. The people dimension has reward and supportiveness as its sub-cultures, where the mean values for both by the PP, SQS and JQS are 4.43, 4.03, 4.05 and 4.43, 4.34, 4.00 respectively. For the external environment dimension, the mean values for stability sub culture by PP, SQS and JQS are $4.48,4.48$ and 4.25 respectively while their mean values for social responsibility sub culture are 4.43, 4.45 and 4.20 respectively. From Table 1 , it could be seen that the mean values for the dimensions of $\mathrm{OC}$ and their sub-dimensions are $\geq 4.00$. The high mean values suggest that culture not only exist, but are pervasive, in QSFs.

The Principal Partner (PP), Senior Quantity Surveyor (SQS) and Junior Quantity Surveyor (JQS) are the hierarchies in QSFs, and except for the supportiveness sub culture, there is insignificant difference in their opinions regarding the dimensions of $\mathrm{OC}$ at $5 \%$ significance level (Table 1). This implies that these hierarchies are unified in their views, which is an advantage to pursuing organisational goals. 
Australasian Journal of Construction Economics and Building

Table 1: Dimensions of organisational culture

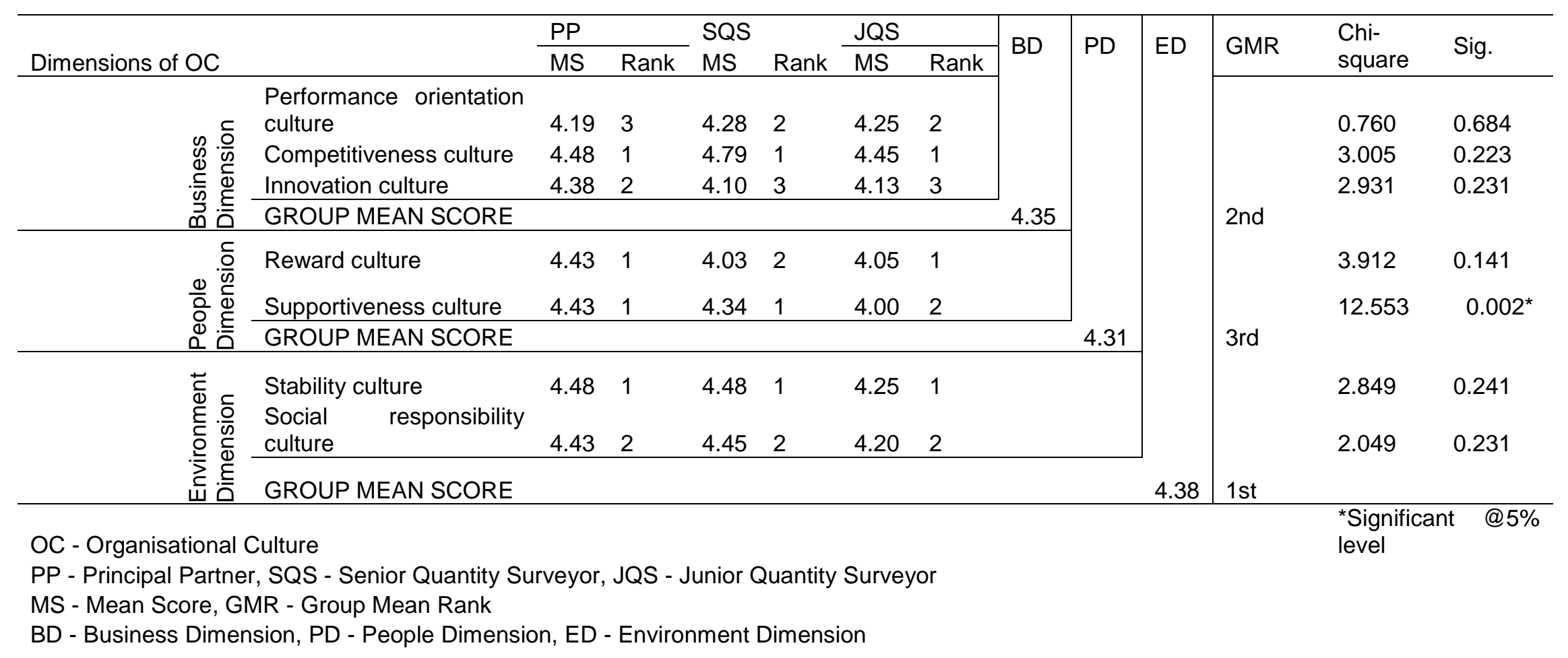




\section{Conclusion}

This paper investigated the DOC in QSFs in Nigeria. It finds that the business, people and the external environment are the DOC in QSFs. This supports the fact that every organisation has a culture (Pandey 2014; Ng \& Kee 2013; Line 1999). However, the problems or challenges confronting QSFs suggest that the importance of their OC has not been appreciated, and therefore not deployed to address the problems. Taking into account the identity and management related problems of QSFs in Nigeria, it may be concluded that $\mathrm{OC}$ is a relevant solution.

The nature of identity problem of QSFs is that their services are not well diffused among relevant stakeholders e.g. clients, policy makers and majority of the public, and therefore not recognised as the professional organisation responsible for cost management in Nigeria. As stated by Hatch and Schultz (1997), the identity of an organisation is expressed through its OC, which is subject to interpretation by others. Also an organization's identity is comprised of its member perceptions, its material features and its actions (Tyworth 2014). By implication, the identity or the diffusion of the services offered by QSFs in Nigeria is a function of the OC exhibited in them.

Specifically, this will affect both the business and people dimensions of OC in QSFS. Notably, the business dimension of OC emphasises on results and competitiveness oriented performance from employees (e.g. Katamba 2010; Delobbe, Haccoun \& Vanderberghe 2005; Davies et al. 2000), while the people dimension of OC is about humanistic concerns such that the personnel in an organisation are motivated to deliver performance (e.g. Khan, Usoro \& Majewski 2010; Vedina \& Vadi 2007). Thus both dimensions of OC operate interdependently. Also, relating the interdependence of both dimensions of OC to the identity problem of QSFs has implications for employee QSs. That is, how QSs in QSFs portray their organisation to the public, and how they contribute to the service quality of the organisation. Both positive perception and quality contribution to service quality are a function of the welfare and support provided by the management to QSs. It is logical for QSs, who are well remunerated and gets their voice heard in organisational matters, to constantly heap praises for the organisation (people dimension of $\mathrm{OC}$ ).

It is also imaginable to expect QSs who are supported with an exquisite and result oriented work environment to deliver high performance (business dimension of OC). These lead to what is called competitive workforce, which are personnel that are well motivated to deliver acme performance. This is an attraction to clients or customers, and the society at large. At this point QSFs are no longer obscure or lacking identity. In construction generally, such organisations are quick to get job commissions from clients because of their capacity to retain quality and motivated workforce. Invariably the organisational performance is improved when there are job commissions and the workforce to deliver them.

Weak organisational structure, outdated operational and inefficient service delivery techniques are the nature of organisational problems identified in QSFs in Nigeria. As in other locations, QSFs in Nigeria are also bedevilled by technological and financial shortcomings. All these can be summed up as management related problems that affect organisational performance. The functionalist paradigm of OC purports that culture can be controlled by managers in organisation. Within this paradigm lies the notion that $\mathrm{OC}$ is instrumental to organisational performance (Fellows 2006). Therefore by implication, the dimensions of $\mathrm{OC}$ are important to solving the organisational or management related problems in QSFs. It is thus incumbent upon managers of QSFs to operate through the lens of their OC. In fact, strategic management theory demands that the culture of organisations be held as an important element in the formulation of any strategy (Barthorpe et al. 2000). Based on this, it could be said that the prevention of management or organisational related problems in QSFs lies in the consideration of their OC by managers, when management actions are taken. 
For instance, an organisation structure (OS) capable of driving the performance of organisations is one that is dynamic and flexible (Sadeghian, Kafashpoor \& Lagzian 2013). That is, OS that can adapt better to the needs of the environment. Among the dimensions of OC, it could be said that implementing OS in QSFs should be in cognizance with the external dimension of OC. Inferring from Nel (2009), taking such cognizance prevents discord with the environment in which the QSF is located. Therefore, instead of weakened OS (Annunike 2011), managers of QSFs can implement a performance enhancing OS by giving proper consideration to OC. The same applies to other management related problems in QSFs, especially the financial related. As an instrument for improving organisational performance, it is well documented in the literature how OC can be adopted to improve financial performance (Yusoff 2011; Davidson, Melinde \& Delene 2007). Thus it could be said that the attaining of competitive financial posture in the QSFs is a function of their OC.

The findings of this research have implications for the management and employees of QSFs and Quantity Surveying researchers. The implications affect employee QSs and managers of QSFs, and the Quantity Surveying academia who have evidently neglected the organisational aspect of the Quantity Surveying profession. The outcome of this study, suggests that for best performance, managers of QSFs in Nigeria should give cognizance to OC when taking management decisions or actions. This approach will not only help in mitigating the existing problems but prevent future organisational performance failures.

Second, the Quantity Surveying academia should direct research focus on various aspects of QSFs, as this has the tendency of providing seminal solutions to recurring problems. This paper adopts survey research design by using the OCP to investigate, and as a basis for describing the OC in QSFs. The possibility remains that the modified OCP questionnaire might not fully capture the OC in QSFs. A mixture of survey and case study (e.g. participant observation) would have enriched the data used in this paper. Thus this paper points to the need for further enquiries using a mixed a research design in studying the OC in QSFs. Also, investigating the relationship between the performance and OC in QSFs will be a significant research.

\section{References}

Abdul Halim, H.A., Ahmad, N.H., Ramayah, T. \& Hanifah, H. 2014, 'The Growth of Innovative Performance among SMEs: Leveraging on Organisational Culture and Innovative Human Capital', Journal of Small Business and Entrepreneurship Development, 2 (1), 107-25.

Abidin, N.Z., Yusof, N., Hassan, H. \& Adros, N. 2010, 'Applying Competitive Strategy in Quantity Surveying firms: An Evolving Process', Asian Journal of Management Research, 2 (1), 61-73.

Abiola-Falemu, J.O., Ogunsemi, D.R. \& Oyediran, O.S. 2010, 'Assessment of Organisational Culture and Innovation Practices of Construction Companies in Southwest Nigeria', In CIB Task Group and Working Commission, P. Barret et al., (ed) TG59 \& W112-Special Track 18th CIB World Building Congress, May 2010, Salford, United Kingdom, 218-33.

Abiola-Falemu, J.O. 2013, 'Organisational Culture, Job Satisfaction and Commitment of Lagos-based Construction Workers', Journal of Business and Management, 13 (6), 108-20.

Aftab, H., Rana, T. \& Sarwar, A. 2012, 'An Investigation of the Relationship between Organizational Culture and the Employee's Role Based Performance: Evidence from the Banking Sector', International Journal of Business \& Commerce, 2 (4), 1-13.

Alas, R., Ubius, U. \& Vanhala, S. 2011, 'Connections between Organisational Culture, Leadership and the Innovation Climate in Estonian Enterprises', In E-Learning Bachelor's, International Prestige. E-Leader, January 2011, Vietnam, 1-15.

Albayrak, G. \& Albayrak, U. 2014, 'Organizational Culture Approach and Effects on Turkish Construction Sector', In 5th International Conference on Chemical, Biological and Environmental Engineering - ICBEE \& 2nd International Conference on Civil Engineering - ICCEN, D. Yang, (ed) APCBEE Procedia, September 2013, New Delhi, India, 252-57. 
Aldhuwaihi, A., Shee, H.K. \& Stanton, P. 2012, 'Organisational Culture and the Job SatisfactionTurnover Intention Link: A Case Study of the Saudi Arabian Banking Sector,' World, 2 (3), 127-41.

Aliyu, M. 2011, 'Need for Specialisations / Faculties in Quantity Surveying Practice,' In Quantity Surveying and the Anti- Corruption Crusade-Achieving Value for Money in Project Cost in Nigeria, Quantity Surveying Assembly and Colloquium, Septmeber 201,1 Abuja, Nigeria, 11-28.

Aluko, M.A.O. 2003, 'The Impact of Culture on Organizational Performance in Selected Textile Firms in Nigeria', Nordic Journal of African Studies, 12 (2), 164-79.

Ankrah, N.A., \& Langford, D.A. 2005, 'Architects and contractors: a comparative study of organizational cultures,' Construction Management and Economics, 23 (6), 595-607. doi: http://dx.doi.org/10.1080/01446190500126973

Ankrah, N.A. 2007, 'An Investigation into the Impact of Culture on Construction Project Performance,' Doctoral Thesis submitted to the University of Wolverhampton, UK.

Annunike, E.B. 2011, 'The changing roles of the Quantity Surveyor in National Development', In Quantity Surveying and the Anti- Corruption Crusade-Achieving Value for Money in Project Cost in Nigeria, Quantity Surveying Assembly and Colloquium, Septmeber 2011, Abuja, Nigeria, 1-10.

Atinuke, J.O. 2010, 'Construction cost data management by quantity surveying firms in Nigeria', In West Africa Built Environment Research (WABER) Conference, S. Laryea et al., (ed), WABER Publishing, July 2010, Accra, Ghana, 247-54.

Barthorpe, S., Duncan, R. \& Miller, C. 2000, 'The pluralistic facets of culture and its impact on construction', Property Management, 18 (5), 335-51. doi: http://dx.doi.org/10.1108/02637470010360632

Bashayreh, A.M. 2009, 'Organizational culture and job satisfaction: A case of academic staffs at Universiti Utara Malaysia (UUM)', Masters Degree thesis, University Utara Malaysia (UUM). Available from: http://etd.uum.edu.my/1632/ 20 November, 2014.

Bowen, P., Cattell, K., Edwards, P. \& Jay, I. 2010, 'Value management practice by South African quantity surveyors', Facilities, 28 (1/2), 46-63. doi: http://dx.doi.org/10.1108/02632771011011396

Cameron, J.E. 2004, 'A three-factor model of social identity,' Self and Identity, 3 (3), 239-62. doi: http://dx.doi.org/10.1080/13576500444000047

Chan, Y. \& Walmsley, R.P. 1997, 'Learning and understanding the Kruskal-Wallis one-way analysisof-variance-by-ranks test for differences among three or more independent groups,' Physical Therapy, 77 (12), 1755-61.

Chong, B.L., Lee, W.P. \& Lim, C.C. 2012, 'The Roles of Graduate Quantity Surveyors in the Malaysian Construction Industry,' International Proceedings of Economics Development \& Research, $37,17-20$.

Coffey, V. 2003, 'The organisational culture and effectiveness of companies involved in public sector housing construction in Hong Kong', In Professionalism in Construction: Culture of High Performance, A. Liu \& Fellows, R., (eds), CIB TG 23 International Conference, October 2003, Hong Kong, 27-43.

Coffey, V., Willar, D. \& Trigunarsyah, B. 2011, 'Profiles of organisational culture in Indonesian construction companies', In the Sixth International Structural Engineering and Construction Conference, S.O. Cheung, (ed), Modern Methods and Advances in Structural Engineering and Construction, June 2011, Zurich, Switzerland. Available from: http://eprints.qut.edu.au/41063/ 20 November 2014.

Corley, K.G. 2004, 'Defined by our strategy or our culture? Hierarchical differences in perceptions of organizational identity and change', Human Relations, 57 (9), 1145-77. doi: http://dx.doi.org/10.1177/0018726704047141

Cortina, J.M. 1993, 'What is coefficient alpha? An examination of theory and applications', Journal of Applied Psychology, 78 (1), 98. doi: http://dx.doi.org/10.1037/0021-9010.78.1.98 
Davidson, G., Melinde C. \& Deléne V. 2007, 'Organisational culture and financial performance in a South African investment bank', SA Journal of Industrial Psychology, 33 (1), 38-48. doi: http://dx.doi.org/10.4102/sajip.v33i1.261

Davies, H.T.O., Nutley, S.M. \& Mannion, R. 2000, 'Organisational Culture and Quality of Health Care', Quality in Health Care, 9, 111-19. doi: http://dx.doi.org/10.1136/qhc.9.2.111

Delobbe, N., Haccoun, R.R. \& Vandenberghe, C. 2005, 'Measuring core dimensions of organizational Culture: A Review of Research and Development of a New Instrument', retrieved 30 October 2012 http:// www.uc llouvain. be/ cps/ucl/doc/iag/ documents/ WP_53_Delobbe.pdf

Dharmayanti, G., Coffey, V. \& Trigunarsyah, B. 2012, 'The impact of organisational culture on project selection: what is the appropriate culture type?', In Advancing Civil, Architectural and Construction Engineering \& Management, Third International Conference on Construction In Developing Countries (ICCIDC-III), July 2012, Bangkok, Thailand, 109-15.

Espejo, R. 2000, 'Self-construction of desirable social systems', Kybernetes, 29 (7/8), 949-63. doi: http://dx.doi.org/10.1108/03684920010342062

Fagbemi, A.O. 2008, 'Assessment of Quantity Surveyors' service quality in Lagos state, Nigeria', M.Tech Thesis Dissertation, Unpublished, Quantity Surveying Department, Federal University of Technology, Akure, Nigeria.

Fellows, R. 2006. Understanding approaches to culture. Construction Information Quarterly, 8 (4), 159-66.

Fong, P.S., \& Choi, S.K.A. 2006, 'A framework of knowledge processes for professional quantity surveying firms in Hong Kong', In Joint International Conference on Computing and Decision Making in Civil and Building Engineering, June 2006, Montréal, Canada, 268-77.

Frei, M., Mbachu, J. \& Phipps, R. 2013, 'Critical success factors, opportunities and threats of the cost management profession: the case of Australasian quantity surveying firms', International Journal of Project Organisation and Management, 5 (1), 4-24. doi: http://dx.doi.org/10.1504/IJPOM.2013.053151

Gajendran, T. \& Brewer, G. 2012, 'Cultural consciousness and the effective implementation of information and communication technology', Construction Innovation: Information, Process, Management, 12 (2), 179-97.

Gajendran, T., Brewer, G., Dainty, A.R. \& Runeson, G. 2012, 'A conceptual approach to studying the organisational culture of construction projects', Australasian Journal of Construction Economics and Building, 12 (2), 26. doi: http://dx.doi.org/10.5130/ajceb.v12i2.2434

Gee, C. 2010, 'The influence of buidling information modelling on the quantity surveying profession', retrieved from http://repository.up.ac.za/handle/2263/16349 on 1 October, 2014.

George, D. \& Mallery, P. 2000, SPSS for Windows Step by Step: A Simple Guide and Reference 9.0 Update, 2nd ed., Allyn and Bacon, Boston.

Giritli, H., Öney-Yazıcı, E., Topçu-Oraz, G. \& Acar, E. 2013, 'The interplay between leadership and organizational culture in the Turkish construction sector', International Journal of Project Management, 31 (2), 228-38. doi: http://dx.doi.org/10.1016/j.ijproman.2012.06.010

Gray, J.H., Densten, I.L., \& Sarros, J.C. 2003, 'Size Matters: Organisational Culture in Small, Medium and Large Australian organisations', Journal of Small Business and Entrepreneurship, 17 (1), 42-53. doi: http://dx.doi.org/10.1080/08276331.2003.10593311

Gray, J.H. \& Densten, I.L. 2005, 'Towards an Integrative Model of Organizational Culture and Knowledge Management', International Journal of Organisational Behaviour, 9 (2), 594-603.

Guevara, B. 2014, 'On methodology and myths: exploring the International Crisis Group's organisational culture', Third World Quarterly, 35 (4), 616-33. doi:

http://dx.doi.org/10.1080/01436597.2014.924064

Hardie, M.P., Miller, G., Manley, K. \& McFallan, S. 2005, 'The quantity surveyor's role in innovation generation, adoption and diffusion in the Australian construction industry', In The Queensland 
University of Technology Research Week International Conference, A. Sidwell, (ed), Conference Proceedings, Queensland University of Technology, July 2005 Brisbane, Australia.

Hatch, M.J., \& Schultz, M. 1997, 'Relations between organizational culture, identity and image. European Journal of marketing', 31 (5/6), 356-65. doi: http://dx.doi.org/10.1108/03090569710167583

Hofstede, G. 1997, 'Cultures and Organizations: software of the mind', McGraw-Hill, New York.

Igo, T. \& Skitmore, M. 2006, 'Diagnosing the organizational culture of an Australian engineering consultancy using the competing values framework', Construction Innovation: Information, Process, Management, 6 (2), 121-39.

Issa, R.R., \& Haddad, J. 2008, 'Perceptions of the impacts of organizational culture and information technology on knowledge sharing in construction', Construction innovation: Information, process, management, 8 (3), 182-201.

Jirasinghe, E.H. 2006, 'Managing \& Measuring Employee Performance' Kogan Page, London.

Johns, R. 2010, 'Survey question bank: Methods Fact Sheet 1, Likert items and scales', University of Strathclyde.

Kadiri, D.S. \& Ayodele, E.M. 2013, 'Constraints to Quantity Surveying Awareness in Nigeria', Civil and Environmental Research, 3 (11), 17-21.

Katamba, D. 2010, 'Corporate Social Responsibility, Organizational Culture, Ethical citizenship and Reputation of Financial Institutions in Uganda', Master Degree Thesis submitted to the School of Graduate Studies, Makerere University, Uganda.

Keng, T.C. \& Ching, Y.K. 2012, 'A study on the use of measurement software in the preparation of bills of quantities among Malaysian quantity surveying firms', In the Ninth International Conference on ICT and Knowledge Engineering, Institute of Electrical Engineers, Piscataway, N.J, January 2011, Bangkok, Thailand, 53-58.

Kessel, F.G., Oerlemans, L.A. \& van Stroe-Biezen, S.A. 2014, 'No creative person is an island: organisational culture, academic project-based creativity, and the mediating role of intraorganisational social ties', South African Journal of Economic and Management Sciences, 17 (1), 4669.

Khan, U.I., Usoro, A. \& Majewski, G. 2010, 'An Organisational Culture Model for Comparative Studies: A Conceptual View', International Journal of Global Business, 3 (1), 53-82.

Lawrence, P.R., \& Lorsch, J.W. 1967, 'Differentiation and integration in complex organizations', Administrative science quarterly, 12 (1), 1-47. doi: http://dx.doi.org/10.2307/2391211

Line, M.B. 1999, 'Types of Organisational Culture', Library Management, 20 (2), 73-5. doi: http://dx.doi.org/10.1108/01435129910251520

Liu, A.N.M., Shuibo, Z. \& Meiyung, L. 2006, 'A framework for assessing organisational culture of Chinese construction enterprises', Engineering, Construction and Architectural Management, 13 (4), 327-342. doi: http://dx.doi.org/10.1108/09699980610680153

Liu, A.M. \& Fellows, R. 2008, 'Behaviour of quantity surveyors as organizational citizens' Construction Management and Economics, 26 (12), 1271-82. doi: http://dx.doi.org/10.1080/01446190802527530

Lok, P. \& Crawford, J. 2004, 'The effect of organisational culture and leadership style on job satisfaction and organisational commitment: A cross-national comparison', Journal of Management Development, 23 (4), 321-38. doi: http://dx.doi.org/10.1108/02621710410529785

Mansor, M. \& Tayib, M. 2010, 'An Empirical Examination of Organisational Culture, Job Stress and Job Satisfaction within the Indirect Tax Administration in Malaysia' International Journal of Business and Social Science, 1 (1), 81-95.

Martins, E.C, \& Terblanche, F. 2003, 'Building organisational culture that stimulates creativity and innovation', European Journal of Innovation, 6 (1), 64-74. doi: http://dx.doi.org/10.1108/14601060310456337 
Mathew, J., Ogbonna, E. \& Harris, L.C. 2012, 'Culture, employee work outcomes and performance: An empirical analysis of Indian software firms', Journal of World Business, 47 (2), 194-203. doi: http://dx.doi.org/10.1016/j.jwb.2011.04.006

Matipa, W.M., Kelliher, D. \& Keane, M. 2009, 'A strategic view of ICT supported cost management for green buildings in the quantity surveying practice', Journal of Financial Management of Property and Construction, 14 (1), 79-89. doi: http://dx.doi.org/10.1108/13664380910942653

Maull, R., Brown, P. \& Cliffe, R. 2001, 'Organisational culture and quality improvement', International Journal of Operations \& Production Management', 21 (3), 302-26. doi: http://dx.doi.org/10.1108/01443570110364614

Nel, L.J. 2009, 'Shared values and organisational culture, a source for competitive advantage: a comparison between Middle East, Africa and South Africa using Competitive Values Framework', published Master Degree dissertation submitted to the Global Institute of Business Science, University of Pretoria.

Ng, H.S. \& Kee, D.M.H. 2013, 'Organisational Culture can be a Double-edged Sword for Firm Performance', Research Journal of Business Management, 7 (1), 41-52. doi: http://dx.doi.org/10.3923/ribm.2013.41.52

Nor, F., Mohamed, O. \& Egbu, C. 2011, 'Knowledge sharing initiatives in quantity surveying firms in Malaysia: Promoting, inhibiting and challenge factors', In: Egbu, C. and Lou, E.C.W. (eds) Procs 27th Annual ARCOM Conference, 5-7 September 2011, Bristol, UK, Association of Researchers in Construction Management, 593-601.

Ofori, G. \& Toor, S. 2012, 'Role of leadership in transforming the profession of quantity surveying', Australasian Journal of Construction Economics and Building, 9 (1), 37-44. doi: http://dx.doi.org/10.5130/ajceb.v9i1.3013

Ogunsemi, D.R., Awodele, O.A. \& Oke, A.E. 2013, An Examination of the Management of Quantity Surveying Firms in Nigeria, delivered at the 2013 Annual Conference of Registered Quantity Surveyors with theme: 'Quantity Surveying Profession: Unbundling Latent Competencies and Developing New Frontiers' Thursday 26th and Friday 27th September, Abuja.

Ojo, O. 2010, 'Organisational Culture and Corporate Performance: Empirical Evidence from Nigeria', Journal of Business System, Governance and Ethics, 5 (2), 1-12.

Olanipekun, A.O. 2012, 'Effects of Organisational Culture on the Performance of Quantity Surveying Firms in Lagos, Nigeria' Master Degree Thesis submitted to the School of Postgraduate Studies, Federal University of Technology, Akure, Nigeria.

Olanipekun, A.O., Aje, I.O. \& Abiola-Falemu, J.O. 2013, 'Effects of Organisational Culture on the Performance of Quantity Surveying firms in Nigeria', International Journal of Humanities and Social Science, 3 (5), 206-15.

Oluwatayo, A.A., Amole, D. \& Adeboye, A.B. 2014, 'Architectural Firms in Nigeria: A Study of Organizational Culture and Determinants', Global Journal of Researches in Engineering: Civil And Structural Engineering, 14 (1), 12-26.

Onwusonye, S.I.J. 2013, 'Quantity Surveying Profession and the Identity Crises', In Quantity Surveying Profession: Unbundling Latent Competencies and Developing New Frontiers, Annual Conference of Registered Quantity Surveyors, September 2013 Abuja, Nigeria.

Oyediran, O.S. 2011, 'Challenges to Efficient Service Delivery by Quantity Surveyors', In Quantity Surveying and the Anti- Corruption Crusade-Achieving Value for Money in Project Cost in Nigeria, Quantity Surveying Assembly and Colloquium, September 2011, Abuja, Nigeria, 77-86.

Pandey, P. 2014, 'Organisational culture-a root to prosperity', Management Insight, 10 (1), 74-80.

Parker, R. \& Bradley, L. 2000, 'Organisational culture in the public sector: evidence from six organisations', International Journal of Public Sector Management, 13 (2), 125-41. doi: http://dx.doi.org/10.1108/09513550010338773 
Pheng, L.S. \& Ming, K.H. 1997 'Formulating a strategic marketing mix for quantity surveyors', Marketing Intelligence \& Planning, 15 (6), 273-80. doi: http://dx.doi.org/10.1108/02634509710184857

Ramachandran, S. 2013, 'A peep into organisational culture', Middle-East Journal of Scientific Research, 15 (12), 1925-27.

Rameezdeen, R. \& Gunarathna, N. 2012, 'Organisational culture in construction: an employee perspective', Australasian Journal of Construction Economics and Building, 3 (1), 19-30. doi: http://dx.doi.org/10.5130/ajceb.v3i1.2908

Sadeghian, S., Kafashpoor, A. \& Lagzian, M. 2013, 'Assessing Impact of Organizational Culture and Organizational Structure on Organizational Effectiveness through Knowledge Management Case Study: Mashhad's Science and Technology Park Author's Details', International Journal of Management Sciences \& Business Research, 2 (12), 24-31.

Sarros, C.J., Gray, J., Densten, I.L. \& Cooper, B. 2005, 'The Organizational Culture Profile Revisited and Revised: An Australian Perspective', Australian Journal of Management, 30 (1), 159-82. doi: http://dx.doi.org/10.1177/031289620503000109

Shaikh, S. 2011, 'The Study on the Relationship between Organisational Culture and Knowledge Management', Journal of Money, Investment and Banking, 19, 21-28.

Smith, P. 2004, 'Trends in the Australian Quantity Surveying Profession 1995-2003', Retrieved from http://epress.lib.uts.edu.au/research-publications/handle/10453/7332 on 30 September 2014.

Smith, P. 2011, 'Information Technology and the QS Practice', Australasian Journal of Construction Economics and Building, 1 (1), 1-21. doi: http://dx.doi.org/10.5130/ajceb.v1i1.2276

Sonia, K.Y.S. 2005, 'A framework of knowledge processes for professional quantity surveying firms in Hong Kong', Retrieved from http://repositor y.lib.polyu. edu.hk/jspui /handle/ $10397 / 3400$ on 1 October 2014.

Su, Z., Yang, D. \& Yang, J. 2012, 'The match between efficiency/flexibility strategy and organisational culture', International Journal of Production Research, 50 (19), 5317-29. doi: http://dx.doi.org/10.1080/00207543.2011.618149

Suppiah, V. \& Sandhu, M.S. 2012, 'Organisational culture's influence on tacit knowledge-sharing behaviour', Journal of Knowledge Management, 15 (3), 462-77. doi: http://dx.doi.org/10.1108/13673271111137439

Tavakol, M. \& Dennick, R. 2011, 'Making sense of Cronbach's alpha', International journal of medical education, 2, 53-55.

Tyworth, M. 2014, 'Organizational identity and information systems: how organizational ICT reflect who an organization is', European Journal of Information Systems, 23 (1), 69-83. doi: http://dx.doi.org/10.1057/ejis.2013.32

Vedina, R. \& Vadi, M. 2007, 'A National Identity Perspective on Collectivistic Attitudes and Perception of Organisational Culture', Baltic Journal of Management, 3 (2), 129-44.

Wilson, E. 2000, 'Inclusion, exclusion and ambiguity-The role of organisational culture', Personnel Review, 29 (3), 274-303. doi: http://dx.doi.org/10.1108/00483480010324652

Wu, Y.H. \& Lin, M.M. 2013, 'The relationships among business strategies, organisational performance and organisational culture in the tourism industry', South African Journal of Economic and Management Sciences, 16 (5), 1-8.

Yin, R.K. 2009, 'Case Study Research: Design and Methods' Sage Publications, California.

Yusoff, W.F.W. 2011, 'Does Organizational Culture Infleunce Firm Performance in Malaysia?', International Journal of Multidisciplinary Research, 1 (3), 1-12.

Zhang, S.B., \& Liu, A.M. 2006, 'Organisational culture profiles of construction enterprises in China', Construction Management and Economics, 24 (8), 817-28. doi: http://dx.doi.org/10.1080/01446190600704604 
Australasian Journal of Construction Economics and Building

Zhou, L., Perera, S., Udeaja, C. \& Paul, C. 2012, 'Readiness of BIM: a case study of a quantity surveying organisation', In: First UK Academic Conference on BIM, D. Greenwood, (ed.), Newcastle Business School \& School of Law, September 2012 Newcastle upon-Tyne, UK, 118-28. 